\title{
The Impact of Electronic Banking on Financial Inclusion in Nigeria
}

\author{
Emeka E. Ene ${ }^{1}$, Gabriel O. Abba², Gideon F. Fatokun ${ }^{3}$ \\ ${ }^{1}$ Department of Accounting \& Finance, Baze University, Abuja, Nigeria \\ ${ }^{2}$ Department of Accounting, Federal University Wukari, Wukari, Taraba State, Nigeria \\ ${ }^{3}$ Central Bank of Nigeria, Abuja, Nigeria \\ Email: *eneelemeka@yahoo.com
}

How to cite this paper: Ene, E.E., Abba, G.O. and Fatokun, G.F. (2019) The Impact of Electronic Banking on Financial Inclusion in Nigeria. American Journal of Industrial and Business Management, 9, 1409-1422. https://doi.org/10.4236/ajibm.2019.96092

Received: May 7, 2019

Accepted: June 27, 2019

Published: June 30, 2019

Copyright $\odot 2019$ by author(s) and Scientific Research Publishing Inc. This work is licensed under the Creative Commons Attribution International License (CC BY 4.0).

http://creativecommons.org/licenses/by/4.0/

(c) (i) Open Access

\begin{abstract}
The concept of financial inclusion has continued to gain global acceptance since it was identified as one of the key drivers of inclusive economic growth and development. Financial inclusion is one of the objectives of the Central Bank of Nigeria's cashless policy introduced in Nigeria in the year 2011. In the light of this, the research seeks to examine the impact of electronic banking on financial inclusion in Nigeria. The study used the total number of automated teller machines and point-of-sale devices in Nigeria as proxies for electronic banking and the proportion of banked adult population to total bankable adult population in Nigeria as proxy for financial inclusion. The study adopted correlational and ex-post facto research designs with the aid of computer-based multiple regression analysis. It was observed that automated teller machines do not significantly impact financial inclusion while point-of-sale devices significantly impact financial inclusion in Nigeria. In line with the findings of the study, it is recommended that deposit money banks should remove the bottlenecks associated with the use of their automated teller machines and strive to meet international best practice. Also, more point-of-sale devices should be readily available and easily accessible by customers.
\end{abstract}

\section{Keywords}

Financial Inclusion, Electronic Banking, Point-Of-Sale, Automated Teller Machine

\section{Introduction}

Financial inclusion, the world over, has been identified as one of the drivers of inclusive economic growth [1]. It is a concept in banking that describes the situ- 
ation where all bankable adults who wish to own a formal financial system bank account have access to one. Notwithstanding the importance of financial inclusion in the growth of any economy, attaining a level where every bankable adult can access financial services remains a global challenge. Kama and Adigun [1] reported that as much as $54 \%$ of bankable adults worldwide do not have access to formal system financial services. The situation is even more worrisome in developing and underdeveloped countries where as much as about $70 \%$ of its bankable adult population are financially excluded or are not able to access formal system financial products and services [1].

Nigeria is the most populous black nation in the world and prides itself as the economic giant of Africa with a population of about 180 million people yet about $43 \%$ of its bankable adult population are financially excluded [1]. In order to improve the level of financial inclusion in Nigeria, the Central Bank of Nigeria which is the apex regulator in the financial sector introduced the cashless policy. The policy is intended to drive the development and modernization of the payment system in Nigeria in one hand, reduce the cost of banking services on the other hand and thirdly to drive financial inclusion by providing more efficient transactions options and greater reach. Thus, the adoption of the cash-less policy has led to remarkable increase in the level of technology (electronic banking) acceptance by deposit money banks in Nigeria and it is evidenced by the increase in the number of automated teller machines, point-of-sales facilities, internet banking, mobile banking, among others.

This study therefore seeks to examine the extent to which electronic banking impacts financial inclusion in Nigeria. In pursuit of this objective, the study seeks to provide answers to the following questions: Does the use of automated teller machines impact financial inclusion in the Nigerian banking industry? To what extent has the adoption of point-of-sale facilities affected financial inclusion in Nigeria?

The next section of the paper presents the review of related literatures on the subject, which is followed by the articulation of methodology of the study and the model specifications. In the fourth section of the paper, the data obtained for the research will be presented and analyzed while the last section contains the conclusions and policy recommendations.

\section{Literature Review}

\subsection{Conceptual Framework}

In this study, the dependent variable is financial inclusion while the independent variable is electronic banking attributes represented by automated teller machines and point-of-sale. Figure 1 below is the conceptual framework for the study.

\subsubsection{The Concept of Financial Inclusion}

A review of literature reveals that there is no universally accepted definition of financial inclusion. Thus, definitions provided by various author and researchers 


\section{Dependent Variable}

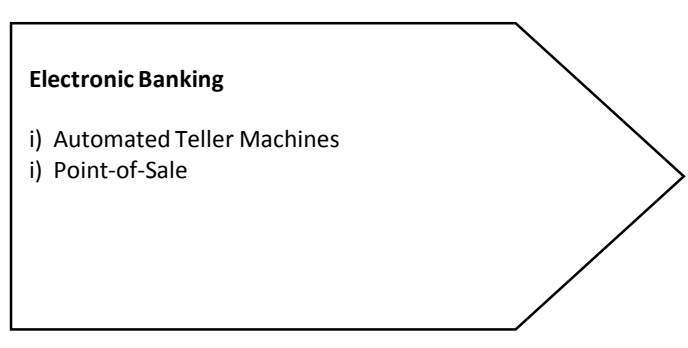

Independent Variables

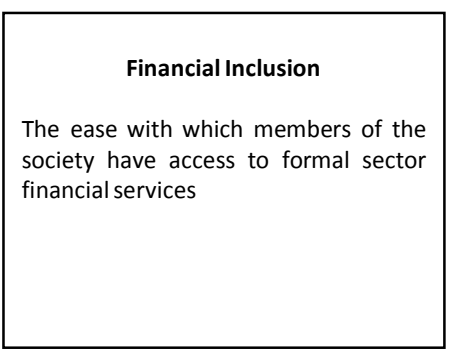

Figure 1. Conceptual framework. Source: Authors, 2018.

focused on different peculiarities such as country exigencies and geographies, the level of social, economic and financial development and priorities of social concerns, among others. Broadly, financial inclusion means access to finance and financial services for all in a fair, transparent and equitable manner at an affordable cost [2]. In a more concise manner, it can be defined as delivery of basic banking services at an affordable cost to all sections of the society, especially the vast sections of disadvantaged and low-income groups who tend to be excluded [3]. According to the Raghuram Committee [4], which is the Committee on Financial Inclusion in India, financial inclusion is the process of ensuring access to financial services and timely and adequate credit where needed by vulnerable groups such as the weaker sections and low-income groups at an affordable cost. This definition focuses on the vulnerable members of the society and ease of access to credit. Along the similar lines, Chakravarty [5] defined financial inclusion as extending the benefits of banking to the have-nots. Simply put, it means that banks will offer a basic account to anyone who wants to have one.

Mohan [6] defined financial inclusion from the point of view of access, fairness, equity and safety in a financial system. The study defined financial inclusion as a coordinated effort by a national or sub-national government to deepen financial services among many customers while providing appropriate low-cost, fair and safe financial products and services or instruments. These services or instruments may include: bank accounts, affordable credit, financial assets, savings schemes, insurance products and services, payments and remittance facilities as well as money advice from mainstream providers to all. Similar views have been expressed by Thorat [7] to whom financial inclusion means the provision of affordable financial services (viz. access to payments and remittance facilities, savings, loans and insurance services) by the formal financial system to those who tend to be excluded. Bernanke [8] adds a new dimension to the understanding of the financial inclusion by saying that it requires substantial efforts in understanding the needs of the customer, counseling, financial literacy, screening and monitoring.

Dev [9] in his definition broadens the scope of financial inclusion by emphasizing the role of new institutional partners like microfinance institutions. The study observed that financial inclusion should not only focus on financial services like credit and savings, but also on an increase in productivity and sustai- 
nability of vulnerable groups in the society [9]. Arunachalam [10] has also expressed a similar view. The study focused on empowering vulnerable members of the society and not merely granting them access to saving accounts in banks. The study opined that financial inclusion should be about going beyond savings bank accounts and consumption credit, to devising/delivering financial products that can help in overcoming market imperfections and facilitate risk management by (and for) the poor in the context of their fragile livelihoods and the vicious cycle of poverty, often caused by structural weaknesses and other factors.

It is therefore obvious from the definitions of financial inclusion in this section that availability and accessibility are two important aspects of financial inclusion. Other aspects include: fairness, equity, economy, safety and quality.

\subsubsection{The Concept of Electronic Banking}

Perhaps, electronic banking is the best innovation that has happened in the banking industry in the $21^{\text {st }}$ Century. Electronic banking has made banking possible away from banking premises. Banking can now take place anywhere using various electronic devices like mobile phones, automated teller machines, point-of-sale systems, smart televisions, computers, tablets, among others. Today different baking transactions can be completed or initiated from different locations outside banking premises such as transfer and receipts of funds, balance enquiry, purchase of airtime, payment of bills and account opening. The question therefore is what is electronic banking? The concept of electronic banking has been defined in many ways by researchers.

Daniel [11] defines the concept as the delivery of information and services by banks to customers via different delivery platforms that can be used on different electronic devices such as personal computers, mobile phones or digital televisions with browsers or desktop software. As good as this definition appears, it does not take into cognizance other platforms for electronic banking such as automated teller machines and point-of-sales which are the focus of this study. Similarly, Abid and Noreen, [12] defined electronic banking as any use of information and communication technology and other electronic means by a bank to conduct transactions and have interaction with stakeholders. This definition is broader than that of Daniel [11] as it focuses on information and communication technology. Also, electronic banking is a system of payment whereby transaction takes place electronically without the use of cash. Magembe and Shemi [13] defined electronic banking (e-banking) as nothing but e-business in the banking industry.

In simple words, e-banking implies provision of banking products and services through electronic delivery channels. Electronic banking has been around for quite some time in the form of automated teller machines (ATMs) and mobile phone transactions. In more recent times, it has been transformed by the internet-a new delivery channel that has facilitated banking transactions for both customers and banks [14]. From these definitions therefore, electronic banking may be viewed as a generic term for describing delivery of banking services and 
products through electronic channels, such as mobile phones, the internet, automated teller machines and point-of-sales facilities.

Similarly, Tiwari and Buse, [15] defined electronic banking as provision of banking and financial services with the help of telecommunication devices such as mobile telecommunication devices. The scope of offered services may include facilities to conduct bank transactions, to administer accounts and to access customized information. In the broader sense electronic banking enables the execution of financial services in the course of which-within an electronic procedure-the customer uses communication techniques in conjunction with telecommunication devices. The most easily accessible electronic platform is mobile banking.

\subsection{Theoretical Framework}

Different theories have been used to explain financial inclusion by researchers. Some of these theories are the financial innovation theory, the technology acceptance theory and the diffusion of innovation theory. Since Nigeria is a developing nation with several challenges associated with technology acceptance, the theoretical framework that closely explains this study is the technology acceptance theory (popularly referred to as TAM) postulated by Davis [16]. The theory is an adaptation of the Reasoned Action Theory (TRAT) specifically tailored for modeling user acceptance of information systems. The goal of (TAM) is to provide an explanation of the determinants of computer acceptance that is general, capable of explaining user behavior across a broad range of end-user computing technologies and user populations, while at the same time being both parsimonious and theoretically justified. Thus, this study believes that the acceptance of contemporary banking technology by customers is fundamental to the performance of these banks as well as the realization of financial inclusion.

\subsection{Empirical Literature}

Empirical literature on the impact of electronic banking on financial inclusion and related topics are myriad producing mixed results and inclusive arguments. For instance, Mago and Chitokwindo [17] examined the impact of electronic banking on financial inclusion in Zimbabwe, with a focus on mobile banking in the Masvingo province. The research adopted a qualitative research methodology and a survey design. They argued that electronic banking significantly impacts financial inclusion in Zimbabwe. Their results show that low income people are willing to adopt mobile banking, thereby enhancing financial inclusion. The reason they argued in this line is that mobile banking is easily accessible, convenient, cheaper, easy to use and secure [17]. Although they adopted an admissible methodology, it could be observed that the scope of their study is too narrow since they under understudied only a province as against the entire country which would have produced a more robust analysis.

In another related study, Bansal [18] adopted qualitative research method to study the role of technology in achieving financial inclusion in rural India. The 
paper attempted to examine the contributions of information and communication technology towards achieving financial inclusion and reducing financial exclusion in the country and analyzed different application of information and communication technology which banks are adopting. The study posit that this would directly or indirectly reflect the effectiveness of the financial institution's efforts to bring-in underprivileged people to the mainstream financial system, especially in rural area support in achieving inclusive growth. The study concluded that modern information and communication technology can act as a tool to develop a platform which helps to extend financial services to remote areas. The study specifically identifies mobile banking and automated teller machines as two promising options for achieving financial inclusion. Thus, the technology of mobile banking and automated teller machines are adding new avenues in providing banking services to the unbanked population who are financially excluded. However, the study is qualitative and relied on previous empirical findings and conclusions which makes it prone to bias and subjectivity.

Asare and Sakoe [19] examined the effects of electronic banking on financial services in Ghana using qualitative research method. The study found out that the advent of electronic banking in Ghana has enhanced accessibility to a wide range of banking products and also delivery of banking services has been made increasingly faster to cover a wide range of customers or people referred by existing customers. Therefore, the study concluded that electronic banking has fundamentally changed the business of banking in Ghana from a financial intermediary to a financial shopping mall providing a one-stop-shop for various financial services [20]. Although the finding of this study was very relevant to the present study, the study however, is not primarily focused on the impact of electronic banking on financial inclusion and moreover, it employed primary data for its analysis which may not be as reliable as secondary data.

Coming from a totally different angle from the works of Mago and Chitokwindo [17] and Asare and Sakoe [19], the study by Maiyaki and Mokhtar [20] undertook a survey of four hundred and seven (407) bank customers in thirty-three (33) organizations in Kano state of Nigeria. Their objective was to analyze the effects of availability of electronic banking facilities among other factors on the bank customers' choice of a banking institution. The study revealed that the availability of electronic banking facilities such as automated teller machine (ATM), online banking and telephone banking do not have a significant influence on customer's bank choice decision. It could be observed however that similar to Asare and Sakoe [19], the study is not primarily focused on the impact of electronic banking on financial inclusion and moreover, they employed primary data for the study which may not be as reliable as secondary data.

In another related study, Kumbhar [21] observed that today almost all banks are adopting information and communication technology as a means to enhance service quality. They are providing information and communication technology-based e-service to their customers in form of electronic banking, internet banking or online banking. It brings convenience and customer centricity, en- 
hances service quality and cost effectiveness in banking and increases customer satisfaction in banking services. Thus, in line with Mago and Chitokwindo [18], they agree that electronic banking positively impacts financial inclusion.

\subsection{Summary of Literature Review}

The subject of electronic banking and financial inclusion has been a topic which has attracted the attention of scholars globally with mixed results. Several of the research efforts employed primary data for their analysis which could be faulted given that primary data are prone to manipulation towards the researcher's desired objectives and conclusions. Some of the studies were mere theoretical examination of the concepts with few adopting data from other researched for analysis and pursuit of research objectives. While some of the conclusions of the reviewed research effort provide an indication that electronic banking impacts financial inclusion positively, some reveal that there is no relationship between the influx of electronic banking technology and the financial inclusion. To make further contribution to existing discussions, the present study uses secondary data obtained from highly reputable institutions in Nigeria to investigate the relationship existing among the research variables. Furthermore, the data obtained were subjected to extensive statistical analysis towards the pursuit of the research objectives.

\section{Methodology}

\subsection{Research Design and Sources of Data}

The research design adopted in this study is ex-post facto research (after-the-event research) and correlational design for a period of ten years (from 2008 to 2017). The population of this study is all the listed deposit money banks in Nigeria as at 31st December, 2017. There were a total of twenty-two [22] listed banks in the Nigerian banking industry that have carried out operations up to 31st December, 2017. The research is a census study as the entire population is studied. Therefore, there was no sampling and sample size since the study covers the entire population. Also, the study uses secondary data for analysis. The study sourced data from Central Bank of Nigeria Banking Operations Department (BOD), Central Bank of Nigeria National Financial Inclusion Strategy 2007-2010 (CBN/NFIS), Central Bank of Nigeria Statistics-Post Cashless Policy (2011-2017), EFInA Survey [22], International and local publications (articles), downloaded from internet, materials and publications sourced from Nigeria Deposit Insurance Corporation (NDIC), National Population Commission and National Bureau of Statistics are relevant to our study.

\subsection{Research Hypothesis and Analytical Tools}

In line with the research objective and following from the opinions gathered from the literature review, two hypotheses, stated in null form, were tested:

$\mathrm{H}_{\mathrm{O} 1}$ : There is no significant relationship between the numbers of automated 
teller machines and financial inclusion in Nigeria.

$\mathrm{H}_{\mathrm{O} 2}$ : The number of point-of-sale systems in Nigeria does not significantly impact financial inclusion in Nigeria.

The technique of data analysis for the research is multiple regression analysis. This technique is preferred for the analysis because the research is empirical in nature and data for the study is time series.

\subsection{Variables Proxies and Measurements}

The proxies for the variables of the study are measured as follows:

Financial Inclusion (FIN)

The dependent variable for the study is financial inclusion. This is the proportion of the bankable population with access to formal sector financial systems' products and services.

Mathematically, financial inclusion is measured as:

$$
F I N_{t}=\frac{N B A B_{t}}{N B A_{t}}
$$

This is usually expressed as a percentage. where:

$F I N_{t}=$ Financial inclusion for the study period $t$.

$N B A B_{t}=$ Number of bankable adults with access to formal sector banking system products and services for period $t$.

$N B A_{t}=$ Number of bankable adults for period $t$.

\section{Automated Teller Machine (ATM)}

The number of ATM is measured as the total number of automated teller machines in the country per annum for all the banks.

This is represented mathematically as:

$$
A T M_{t}=\sum A T M_{t}
$$

where:

$A T M_{t}=$ Automated Teller Machines for study period $t$.

$\sum A T M_{t}=$ Summation of Automated Teller Machines in the Banking industry for period $t$.

\section{Point-of-Sale Machine (VPOST)}

POS is measured as the total number of point-of-sales machines in the country per annum for all the banks.

This is represented mathematically as:

$$
\mathrm{POS}_{t}=\sum \mathrm{POS}_{t}
$$

where:

$P O S_{t}=$ Point-of-sales Machines for study period $t$.

$\sum P O S_{t}=$ Summation of point-of-sales Machines in the Banking industry for period $t$.

\subsection{Model Specification}

The following model has been developed for the study: 


$$
F I N_{t}=\beta_{0}+\beta_{1} A T M_{t}+\beta_{2} P O S_{t}+\varepsilon_{t}
$$

where:

$F I N_{t}=$ Financially included adult population in the country for period $t$.

$A T M_{t}=$ Number of automated teller machines in the country for period $t$.

$P O S_{t}=$ Number of point-of-sales machines in the country for period $t$.

$\beta_{0}=$ Intercept

$\beta_{1-2}=$ Coefficient of the independent variables

$\varepsilon_{t}=$ Residual or error term for period $t$

$t=$ period

\section{Data Presentation and Analysis}

\subsection{Descriptive Statistics}

As shown in Table 1, a total of 10 observations were made for each of the study variables and 30 observations for the three variables. FIN which represents the level of financial inclusion in the Nigerian banking industry has an average of $56 \%$ over the ten-year period of the study and ranges from $47 \%$ to $60 \%$. This shows that only about $56 \%$ of Nigeria's bankable populations have access to financial products and services of the formal financial system in the economy. This therefore means that about $44 \%$ of the bankable adult population is financially excluded. This may not be far from reality as many people in the rural areas are either not reached by the financial sector or do not understand the need for bank accounts. This may be attributed to illiteracy, low income and poverty, difficulty in accessing the closest branch of a bank, absence of automated teller machines or point-of-sale facilities and the nature of the ease of electronic services. As a result, the rural dwellers prefer the local financial arrangements such as the "Ajo" in the western part of Nigeria, "Esusu" in the eastern part of Nigeria and "Adashe" in the northern part of Nigeria. The officials of these local arrangements can be seen even in urban markets on daily basis collecting members' contributions in the market.

Furthermore, an average of about 12,764 automated teller machines was available for the banking industry during the period of the study. This number of automated teller machines is considered grossly inadequate for Nigeria's population which currently stands at about 188 million people with over 80 million adults. Most of the rural communities are not fitted with functional automated teller machines, thereby making accessibility to baking services outside working

Table 1. Descriptive statistics of the dependent and independent variables.

\begin{tabular}{cccccc}
\hline Variables & Observations & Mean & Std. Dev. & Minimum & Maximum \\
\hline FIN & 10 & 56.08 & 5.207 & 47.5 & 60.5 \\
ATM & 10 & $12,764.7$ & 3720.53 & 8,075 & 17,449 \\
POS & 10 & $69,269.6$ & $51,922.71$ & 5,000 & 120,191 \\
\hline
\end{tabular}

Source: Author's computation using SPSS 16. 
hours and days difficult. Also, in the urban areas with lots of automated teller machines, it is common to see five automated teller machines installed in a location with only one loaded with cash. Thus, most of the automated teller machines points are always characterized by long and unending queues.

Finally, the average number of point-of-sale facilities in the Nigerian banking industry during the period of the study is about 69,270 . This figure is way above that of automated teller machines in the Nigerian banking industry, thereby making point-of-sale machines more accessible by bank customers. This may be due to the fact that point-of-sale facilities are cheaper to obtain and install and highly portable.

\subsection{Analysis of Results}

The summary of multiple regression analysis using ordinary least square is presented in Table 2.

Table 2 shows that the coefficient of POS is positive and significant at the $5 \%$ level. The coefficient is quite high and very much higher than the coefficient of ATM in the model. The coefficient of ATM is positive and not significant at the $5 \%$ level and very low. It is therefore inferred from this results that point-of-sale (POS) is the most significant determinant of financial inclusion in the model. This means that when the number of point-of-sales increases by a unit in the Nigerian banking industry, financial inclusion increases by about $5 \%$. On the other hand, a reduction in the number of point-of-sales facilities by a unit, will lead to about $5 \%$ reduction in financial inclusion in the Nigerian banking industry. The significant positive relationship between the number of point-of-sales facilities and financial inclusion may not be unconnected with the ease of access and availability. Although there could be problems associated with the use of point-of-sales such as network failure and power challenges, it is still an easy means of payment in Nigeria.

Although, the number of automated teller machines (ATM) is positively related with financial inclusion, the coefficient of regression is not significant and

Table 2. Stata 11 regression results using ordinary least square (OLS).

\begin{tabular}{cccc}
\hline Statistics & $\begin{array}{c}\text { Standardized } \\
\text { Coefficients }\end{array}$ & t-Values & Significance \\
\cline { 1 - 1 } Variables & Beta & $\mathrm{T}$ & Sig. \\
Dependent & 0.048 & 0.169 & 0.871 \\
ATM & 0.838 & 2.951 & 0.021 \\
POS & & 0.77 & \\
$\mathbf{R}^{2}$ & & 0.70 & \\
Adjusted $\mathbf{R}^{2}$ & & $\mathbf{1 1 . 4 2 0}$ & \\
F-Statistic & & $\mathbf{0 . 0 0 6}$ & \\
Significance & &
\end{tabular}

Source: Author's computation using SPSS 16, 2018. 
also very low, at about $5 \%$ as against the coefficient of point-of-sale (POS) which is about $84 \%$. This result reveals the reality of the experience of Nigerian bank customers both in the urban and rural areas in the use of automated teller machines. Automated teller machines in Nigeria are bedeviled by different challenges. These automated teller machines are often not loaded with cash. Even when they are loaded, they are often slow and time wasting. Long queues also characterize the Nigerian automated teller machine points. At times, the queues at the automated teller machine points are more than that in the banking premises, and customers are discouraged from using them and prefer counter transactions, thereby defeating the purpose of the use of automated teller machines. Network problems are also common with the Nigerian automated teller machines. Often, the machines report out of service, leaving customers wondering when the service will be restored. Technical faults are also common such as dispense error where customers' accounts are debited without release of cash or non-release of cards after use by the machine, among other issues and challenges. These reasons may have accounted for the insignificant relationship between financial inclusion and the number of automated teller machines in Nigeria as well as the low beta value in the model [23].

The cumulative regression statistics also reveal significant results on the study. Furthermore, Table 2 shows that $\mathrm{R}^{2}$ is 0.77 and significant at $1 \%$. This signifies that about $77 \%$ of total variation or change in financial inclusion is caused by changes in the number of automated teller machines and point-of-sale facilities. The high value of $\mathrm{R}^{2}$ implies that the estimated model has high forecasting power, since only about $23 \%$ of the variations in financial inclusion (FIN) were left unaccounted for by the model, hence captured by the error term in the model. The Adjusted $\mathrm{R}^{2}$ for the model is about $70 \%$. Since the adjusted $\mathrm{R}^{2}$ is very close to the coefficient of determination, this further proves that the mode is fit, and the explanatory variables are properly selected, combined and used.

\subsection{Test of Hypothesis}

Thus, two hypotheses have been developed and tested using multiple regression results through the instrumentality of SPSS 16.

The regression results used for the test of hypotheses of the study are extracted from Table 2 and are presented in Table 3.

\subsubsection{Hypothesis 1}

$\mathrm{H}_{\mathrm{O} 1}$ : There is no significant relationship between the numbers of automated teller machines (ATM) and financial inclusion (FIN) in Nigeria.

The regression result shown in Table 3 reveals that financial inclusion (FIN) is positively but not significantly related to the number of automated teller machines in Nigeria with a beta coefficient of 0.048 which is quite low and t-value of approximately 0.169 both of which are not significant at any level. The result therefore provides the basis for not rejecting the null hypothesis which states that there is no significant relationship between the number of automated teller 
Table 3. Result of test of hypotheses.

\begin{tabular}{cccc}
\hline Statistics & $\begin{array}{c}\text { Standardized } \\
\text { Coefficients }\end{array}$ & t-Values & Significance \\
\cline { 1 - 3 } Variables & Beta & $\mathrm{T}$ & Sig. \\
Dependent & 0.048 & 0.169 & 0.871 \\
ATM & 0.838 & 2.951 & 0.021 \\
POS & &
\end{tabular}

Source: Author's computation using SPSS 16, 2018.

Table 4. Summary of hypotheses testing.

\begin{tabular}{|c|c|c|c|c|}
\hline Independent Variable & Expected Sign & Reported Sign & $\begin{array}{c}\text { Significant or not } \\
\text { Significant }\end{array}$ & Remarks \\
\hline \multicolumn{5}{|c|}{ Test of Hypothesis One } \\
\hline $\begin{array}{l}\text { Automated Teller } \\
\text { Machines (ATM) }\end{array}$ & Nil & + & Not Significant & $\begin{array}{c}\text { Hypothesis one } \\
\text { not rejected }\end{array}$ \\
\hline \multicolumn{5}{|c|}{ Test of Hypothesis Two } \\
\hline Point-of-Sale (POS) & + & + & Significant @ 5\% & $\begin{array}{l}\text { Hypothesis two } \\
\text { rejected }\end{array}$ \\
\hline
\end{tabular}

Source: Result of the study (2018).

machines and financial inclusion in Nigeria. This result was not expected from the on-set of the study. Therefore, the study fails to reject the null hypothesis 1 .

\subsubsection{Hypothesis 2}

$\mathrm{H}_{\mathrm{O} 2}$ : The number of point-of-sale systems (POS) does not significantly impact financial inclusion (FIN) in Nigeria.

According to Table 3, test of hypothesis also reveals a significant positive relationship between financial inclusion and number of point-of-sale systems in $\mathrm{Ni}$ geria. The coefficient for point-of-sale of about 0.84 , is significant at the $5 \%$ level with a t-value of 2.951 and significant at $1 \%$. Therefore, the study rejects the null hypothesis 2 which states that the number of point-of-sales systems (POS) in Nigeria does not significantly impact financial inclusion. The study finds out that there is strong positive relationship between financial inclusion and the number of point-of-sale systems in Nigeria. The summary of hypothesis testing (Table 4) also reveals that there is a strong positive relationship between financial inclusion and the number of point of sales system in Nigeria.

\section{Conclusion}

Achieving financial inclusion has been the target of governments around the world, especially underdeveloped and developing economies. Thus, financial inclusion is seen by researchers as one of the key drivers of economic growth and development which informed this research effort. Towards contribution to existing knowledge, this research effort attempted to identify the key drivers of financial inclusion in the wake of Central Bank of Nigeria's cashless policy. The study finds out that electronic banking is positively related to financial inclusion. Specifically, the study 
concludes that point-of-sale (POS) systems are major drivers of financial inclusion while the challenges associated with the use of automated teller machines (ATM) hamper their contribution to financial inclusion (FIN) in Nigeria.

\section{Recommendations}

In line with the objectives, analysis and findings of the study, the following recommendations have been made for policy improvement:

1) A deliberate policy that will enhance the performance of automated teller machines of banks should be made by the apex regulator of the Nigerian banking system. This policy should among others, ensure that automated teller machines installed by banks meet international best standards.

2) Deposit money bank should ensure that automated teller machines provide convenience for customers by installing more of them since they have been found to be inadequate by this research.

3) Central Bank of Nigeria should intensify its campaign for the acceptance of electronic banking by the bankable population since it has been identified as one of the major drivers of financial inclusion.

Since point-of-sale facilities have been identified as a significant driver of financial inclusion, the Central Bank of Nigeria and deposit money banks should make it more accessible to all categories of businesses in the country while improving its operational efficiency.

\section{Conflicts of Interest}

The authors declare no conflicts of interest regarding the publication of this paper.

\section{References}

[1] Kama, U. and Adigun, M. (2013) Financial Inclusion in Nigeria: Issues and Challenges. Central Bank of Nigeria, Abuja, Occasional Paper No. 45. https://doi.org/10.2139/ssrn.2365209

[2] Thingalaya, N.K., Moodithaya, M.S. and Shetty, N.S. (2010) Financial Inclusion.

[3] Leeladhar, V. (2005) Taking Banking Services to the Common Man.

[4] Raghuram Committee (2008) A Hundred Small Steps-A Report of the Committee on Financial Sector, India.

[5] Chakrabarty, K.C. (2010) Inclusive Growth-Role of Financial Sector. National Finance Conclave, Bhubaneswar, 27 November 2010, 23-39.

[6] Mohan, R. (2006) Economic Growth, Financial Deepening and Financial Inclusion. Annual Bankers Conference, Hyderabad, 3 November 2006, 72-95.

[7] Thorat, U. (2007) Financial Inclusion-The Indian Experience. HMT-DFID Financial Inclusion Conference, London, 19 June 2007, 22-33.

[8] Bernanke, B.S. (2006) Global Economic Integration: What's New and What's Not? 30 th Annual Economic Symposium, Jackson Hole, 25 August 2006, 113-132.

[9] Dev, S.M. (2006) Financial Inclusion: Issue and Challenges. Economic and Political Weekly, 41, 4310-4313. 
[10] Arunachalam, R.S. (2008) Scoping Paper on Financial Inclusion, Considerations and Recommendations for UNDP. http://www.in.undp.org/content/dam/india/docs/scoping_paper_on_financial_incl usion.pdf

[11] Daniel, E. (1999) Provision of Electronic Banking in the UK and the Republic of Ireland. International Journal of Bank Marketing, 17, 72-82. https://doi.org/10.1108/02652329910258934

[12] Abid, H. and Noreen, U.C. (2006) Ready to E-Bank: An Exploratory Research on Adoption of E-Banking and E-Readiness in Customers among Commercial Banks in Pakistan. Working Paper Series.

[13] Magembe, S. and Shemi, A.P. (2002) Challenges and Opportunities for Adopting Electronic Commerce in a Developing Country: The Botswana Perspective. IAABD Conference Proceedings, Port Elizabeth, June 2002, 212-235.

[14] Nitsure, R.R. (2003) E-Banking: Challenges and Opportunities. Economic and Political Weekly, 38, 5377-5381.

[15] Tiwari, R. and Buse, S. (2007) The Mobile Commerce Prospects: A Strategic Analysis of Opportunities in the Banking Sector. Hamburg University Press, Hamburg.

[16] Davis, F.D. (1989) Perceived Usefulness Perceived Ease of Use, and User Acceptance of Information Technology. MIS Quarterly, 13, 319-340. https://doi.org/10.2307/249008

[17] Mago, S. and Chitokwindo, S (2014) The Impact of Mobile Banking on Financial Inclusion in Zimbabwe: A Case for Masvingo Province. Mediterranean Journal of Social Sciences, 5, 221-230.

[18] Bansal, S. (2014) Perspectives of Technology in Achieving Financial Inclusion in Rural India. Procedia Economics and Finance, 11, 472-480. https://doi.org/10.1016/S2212-5671(14)00213-5

[19] Asare, M. and Sakoe, J. (2015) The Effects of Electronic Banking on Financial Services in Ghana. Research Journal of Finance and Accounting, 6, 147-154.

[20] Maiyaki, A.U. and Mokhtar, S.S.M. (2010) Effects of Electronic Banking Facilities, Employment Sector and Age-Group on Customers Choice of Banks in Nigeria. Journal of Internet Banking and Commerce, 15, 119-128.

[21] Kumbhar, V.M. (2011) E-Banking and Its Impact on Customers' Satisfaction: A Case Study of Public and Private Sector Banks in Satara City. Ethos: A Journal of Research Article in Management Sciences and Allied Areas, 4, 72-79.

[22] EfInA (2014) Supply Side: The Impact of Financial Inclusion Policies on Deepening Financial Inclusion in Nigeria.

[23] Adeniran, L.M. and Junaidu, A.S. (2014) An Empirical Study of Automated Teller Machines and User Satisfaction in Nigeria: A Study of United Bank for Africa in Sokoto Metropolis. International Journal of Management Technology, 2, 1-11. 